\title{
Profile of Students' Critical and Creative Thinking Skills
}

\author{
Nia Alfitriyani*, Indarini Dwi Pursitasari, Surti Kurniasih \\ Science Education Study Program \\ Graduate School of Pakuan University \\ Bogor, Indonesia \\ *niaalfitriyani@gmail.com
}

\begin{abstract}
This study aims to profile the critical and creative thinking skills of high school students in science. The research was employed a quantitative descriptive method. The participants involved in the research were consisted of 108 students for critical thinking skill measurement and 129 students for creative thinking skill assessment. The sample was determined by random cluster sampling. The students' critical thinking skills was measured using 5 essay questions which assess aspects of reasoning, inferencing, situations, clarity, and overviewing. In addition, the 4 essay questions were used to assess students' creative thinking skills on aspect of fluency, flexibility, originality, and elaboration. The results of the findings revealed that students' critical and creative thinking skills are still in the low category, indicating the lack of students understanding in science concepts.
\end{abstract}

Keywords-critical thinking skill, creative thinking skill, science subject

\section{INTRODUCTION}

COVID-19 is a highly contagious virus and a pathogen caused by acute respiratory syndrome, namely coronavirus 2 (SARS-CoV-2), which emerged in Wuhan, China, and spread throughout the world [1-3]. The Covid-19 pandemic has had many changing impacts in various fields, including education [4]. One of the government policies is to close schools [5] and turn them into online learning. The impact of the Covid-19 pandemic raises much anxiety in the process of adapting to the changes that occur [6]. It raises the hypothesis that student performance and the percentage of passing school students will decrease [7]. Therefore, in facing the new normal era, there is a need to explore education in facing the challenges that arise [8]. The education curriculum must be strengthened with more responsive practices to student learning needs [9]. Based on the research results of Aliyyah et al. [10], the success of learning online in Indonesia during the Covid-19 pandemic is determined by the readiness of technology and curriculum that develop as needed. Besides, online learning that uses all-digital access requires thinking skills in using it [11]. Therefore, a teacher must create a learning process that achieves students' thinking skills and develops students' soft skills during the Covid-19 pandemic [12]. Even though learning has turned into online learning, the development of soft skills and 21st-century skills that have been integrated into the 2013 curriculum must still be applied [13].

The skills needed by 21 st-century students are skills that can answer various challenges [14], including the impact of this Covid-19 pandemic. Besides being useful in everyday life to respond to the challenges of changing times, 21st-century skills are needed to produce competent student graduates so they can compete in the world of work [15]. According to Chalkiadaki's [16] research results, there are four categories of 21 st-century skills, and they are personal skills (including critical thinking and creative thinking), social skills (including communication skills and collaboration), information, and knowledge (such as metacognition abilities), and digital literacy (literacy towards the use of media and ICT). Meanwhile, Van et al. [17] argued that the core of 21st-century skills is information, communication, collaboration, critical thinking, creativity, and problem-solving skill. Another opinion states that 21 st-century skills that are appropriate to produce students, workers, and citizens who can participate in the economy and knowledge in the future society, namely critical thinking, decision making, problem-solving, communication, cooperation, responsibility, and creativity [18]. 21st-century skills were also described from US-based Partnership for 21st Century Skills (P21), which identifies the competencies needed in the 21st century, namely "The 4Cs" - communication, collaboration, critical thinking, and creativity $[19,20]$.

Apart from the various opinions regarding the skills needed in the 21st century, the Covid-19 pandemic situation requires learning to teach students to think critically in dealing with issues circulating in society [21]. The Covid-19 pandemic has resulted in several problems that require thinking skills to produce creative and innovative solutions [22]. Creative and innovative solutions are the result of trained creative thinking $[23,24]$. Students with good creative thinking skills can be flexible and see challenges as opportunities in a world that continues to proliferate [25]. Critical and creative thinking skills are proven to have a significant relationship in improving student learning outcomes [26]. These thinking skills need to be developed through the learning process and are still a challenge for teachers today [27]. 
The shift in learning objectives to equip students with 21 stcentury skill competencies poses challenges in the implementation of learning. Learning models and strategies are an essential key to ensuring these goals are achieved [28]. Teachers must be able to choose the right learning models and strategies in online learning [29-31] and integrate them with critical and creative thinking skills. Before implementing this learning, it would be better if a teacher knows the initial abilities of students so that the learning process given to students is right on target [32,33]. The knowledge of students' initial abilities can be a benchmark in improving skills [33], including students' critical and creative thinking skills and improving the quality of previous and current learning [34].

Based on the results of an interview with a science teacher at a junior high school in West Java, teachers have never conducted a test to measure 21 st-century skills, including critical and creative thinking skills. So that the learning process carried out does not measure critical and creative thinking skills directly. Efforts to improve critical and creative thinking skills have been made, such as using various strategies and learning models. However, teachers are not able to see the effectiveness of the efforts to improve these critical and creative thinking skills. Therefore, it is essential to test critical and creative thinking skills as the knowledge of students' initial abilities. Furthermore, this knowledge of initial abilities can be used as evaluation material in a higher quality learning process in improving 21 st-century skills.

\section{RESEARCH Methodology}

\section{A. Research Design}

This study used a descriptive method that aims to profile students' critical and creative thinking skills without altering or manipulating the learning situation for students.

\section{B. Targets/Participants}

The research was carried out at one of the Islamic schools in Majalengka. The research sample was students of grade VIII, and consisting of 108 students for critical thinking skill tests participants and 129 students for creative thinking skill tests participants. Both samples were determined through random cluster sampling. The reason to use the sampling method is that it has the advantage of simplifying the collection of sample information [35]. The characteristics of students have the average learning ability from low to moderate. The majority of the parents' economy is from low to medium level, with a livelihood of micro traders. So that most parents pay less attention to student learning development.

\section{Data Collection}

Data collection techniques are carried out by collecting primary data through tests to measure critical and creative thinking skills, as well as secondary data through notes and interviews to examine problems in more depth in order to complement and support the primary data needed in research.

\section{Research Instruments}

The critical thinking test instrument consists of 5 essay questions, and each represents every aspect of critical thinking skill. The questions are valid questions based on the validity test by expert judgment. Aspects of critical thinking skills used in the study are in Table 1.

TABLE I. ASSESSMENT ASPECTS OF CRITICAL THINKING SKILLS

\begin{tabular}{|l|l|}
\hline \multicolumn{1}{|c|}{ Aspect } & \multicolumn{1}{c|}{ Description } \\
\hline Reason & Students can reveal the reasons for the answer \\
\hline Inference & Students can estimate the conclusions will be obtained \\
\hline Situation & $\begin{array}{l}\text { Students can apply the previously owned knowledge } \\
\text { concepts to solve problems in other situations }\end{array}$ \\
\hline Clarity & $\begin{array}{l}\text { Students can give examples of problems or questions that } \\
\text { are similar to those that already exist in the subject } \\
\text { material }\end{array}$ \\
\hline Overview & $\begin{array}{l}\text { Students check the correctness of answers to the subject } \\
\text { material }\end{array}$ \\
\hline
\end{tabular}

The creative thinking test instrument consists of 4 essay questions. Each question does not depend on other questions and represents every aspect of creative thinking skill. The creative thinking test instrument is a valid test instrument based on expert judgment. Aspects of creative thinking skills used in the study are in Table 2 .

TABLE II. ASSESSMENT ASPECTS OF CREATIVE THINKING SKILLS

\begin{tabular}{|l|l|}
\hline \multicolumn{1}{|c|}{ Aspect } & \multicolumn{1}{c|}{ Description } \\
\hline Fluency & Students can give ideas to solve problems \\
\hline Flexibility & $\begin{array}{l}\text { Students can give a variety of responses to questions } \\
\text { given }\end{array}$ \\
\hline Originality & $\begin{array}{l}\text { Students can give an idea or answer with their language } \\
\text { and ways }\end{array}$ \\
\hline Elaboration & Students can give a detailed answer \\
\hline
\end{tabular}

\section{E. Data Analysis}

Data analysis of the results of critical and creative thinking skills was carried out by giving scores on students' answers. According to the rubric of the assessment, the value of the score is $0,1,2,3$, or 4 per the assessment indicator. Scores of critical and creative thinking skills were obtained using equation (1). Based on equation (1), the maximum score for critical and creative thinking skills is 100 [37].

$$
\text { Ideal }=\frac{\text { scores obtained }}{\text { maximum score }} \times 100
$$

Then the score obtained is converted into a percentage and classified into the Very Low category $(\leq 20 \%)$, Low $(21 \%$ $40 \%)$, High (41\%-6-\%), and Very High (81\%-100\%) [37].

The quantitative data obtained were then analyzed descriptively. Interviews were conducted on the results of tests of critical and creative thinking skills to obtain more detailed information. 


\section{RESULTS AND DISCUSSIONS}

\section{A. Critical Thinking}

Indicators used or measured in the critical thinking skill test are: reason, the indicator is providing reasons for the answers or conclusions; inference, the indicator is estimating the conclusions to be obtained; situation, the indicator is applying the concept of prior knowledge to solve problems in other situations; clarity, the indicator is providing examples of problems similar to those that already exist; overview, the indicator is checking the correctness of the answer. The results of the critical thinking skill test are in graphical form in Figure 1.

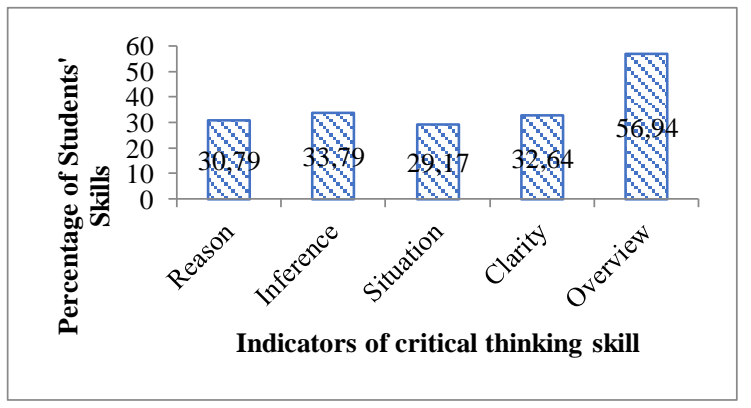

Fig. 1. The results of students' critical thinking skill.

Based on Figure 1, the results of students' critical thinking skills on the five indicators tested had various values. The highest score is in the overview indicator with $56.94 \%$, and the lowest value in the situation indicator with $29.17 \%$. Each of these indicators can be interpreted on the value category according to Arikunto [37], which is in Table 3.

TABLE III. THINKING SKILL VALUE CATEGORY

\begin{tabular}{|l|l|l|}
\hline $\begin{array}{c}\text { Indicator of Critical } \\
\text { Thinking Skill }\end{array}$ & Value (\%) & \multicolumn{1}{c|}{ Category } \\
\hline Reason & 30,79 & Less critical \\
\hline Inference & 33,79 & Less critical \\
\hline Situation & 29,17 & Less critical \\
\hline Clarity & 32,64 & Less critical \\
\hline Overview & 56,94 & Quite critical \\
\hline Average & 36,67 & Less critical \\
\hline
\end{tabular}

Indicators of reason, inference, situation, and clarity have values of critical thinking skills with the category "Less Critical," and the indicator of overview has critical thinking skills in the category of "Quite Critical." The indicator of overview gets the highest value of $56.94 \%$. It illustrates that students are quite careful in re-checking the answers given as a whole.

Students answered correctly, fixing the table on questions regarding pairs of types of environmental pollution with the impact of environmental pollution. Students are careful enough to find out the mistakes that exist in the questions so that they can correct them. The following is an excerpt from interviews with students regarding the answers given.

Q: Try to explain how you know if the table of pairs of types of environmental pollution with environmental pollution impacts presented in the question is wrong!

A: I see that every type of environmental pollution starting from water, soil, air, and sound has an imprecise impact on the pollution, while the counterpart is in another column. Automatically I choose all the right pollution impacts according to the type of pollution.

$Q$ : How do you know that the pair of pollution impact you chose is correctly matched with the type of pollution listed in the table?

A: I read one by one carefully, ma'am ... after that, I made a new table and filled in the pairs of types of pollution with the impact of pollution that I knew first. And the most difficult being the last pair that I write down.

The indicator of the situation gets the lowest score of $29.17 \%$. The situation here means that students can answer questions according to the context of the problem. Students with low ability are only able to focus on what is known and asked only and can only mention the previous material related to problem-solving without solving the problem.

In the questions of the situation indicator, the teacher asked students to answer about the steps to find out whether water is polluted or not. Students can answer it if they use their prior knowledge to solve a problem in another situation. Most students answered according to the context in the case story text provided, not with their prior knowledge of the concept of polluted waters. The following is an excerpt from interviews with students regarding the answers they have given.

Q: Now, try to explain the answers you have given to question number 3! Where can you answer that question?

A: I read in the text about ma'am, there is black polluted water and a lot of garbage on the edge of the water.

Q: Previously, do you know how the characteristics of a polluted water?

\section{A: I don't know ma'am}

The average value of students' critical thinking skills was $36.67 \%$, with the category "Less Critical." It shows that the critical thinking skills of students at Madrasah Tsanawiyah are in the low or less critical category.

The critical thinking skills of students at Madrasah Tsanawiyah in Majalengka are in a low category. It is evidenced by the results of the critical thinking skills test with a value of 36.67 in the less critical category. The findings of 
these results are in line with research conducted by Rahayu [38], Dewi et al. [39], Alifia and Saputro [40], and Widodo and Sunarmo [41] that students' critical thinking skills are still low. Many factors cause poor critical thinking skills in students, such as a lack of a learning process that trains critical thinking skills [42], as well as a lack of learning innovation in terms of learning models and media that can train students to think systematically [43]. Critical thinking skills need to be integrated as pedagogy so that they can become habitual thinking [44]. Critical thinking skills can be trained in learning. There are a variety of learning methods such as using scientific learning [45], game-based learning that involves problemsolving activities [46], applying a constructivist environmentbased web learning model [47], and using the Socrates' Question and Answer strategy [48]. There are many different kinds of learning innovations that can be applied. However, teachers play an essential role in creating learning to encourage students to think critically [45].

Students at MTSN 6 Majalengka are quite thorough when working on critical thinking skill questions. It is evidenced by the value of the indicator of the overview, which reaches the highest value, among other indicators. In the interview, students were careful enough to see the errors in the table pairs of types of pollution with the impact of pollution. Besides, students are also able to correct these mistakes and write them down with the answers they think are correct. Based on the research results of Ulfa et al. [46], familiarizing students with re-checking the answers given as a whole can train students' accuracy so that students can find alternative answers to solve problems. It is called as the overview skill. The lowest indicator that students get during a creative thinking skill test is the indicator of the situation. Based on the results, the students answered not based on their knowledge, but from the existing discourse on the questions. Students do not answer questions by expressing essential things based on the knowledge they have. According to Rahimah [47], students with low scores on the indicator of the situation are unable to reveal important factors that need to be considered in assessing and deciding. The discourse or phenomenon that is presented in the question provokes students to express their knowledge in answering a problem [48].

\section{B. Creative Thinking}

Indicators of creative thinking studied are: fluency, is the ability to reveal several problems or questions with the correct answer; flexibility, is the ability to produce various answers; elaboration, is the ability to explain, itemize, and develop ideas or answers given; and originality, is the ability to provide ideas or answers in their language and way. The results of the students' creative thinking skill test are in Figure 2.

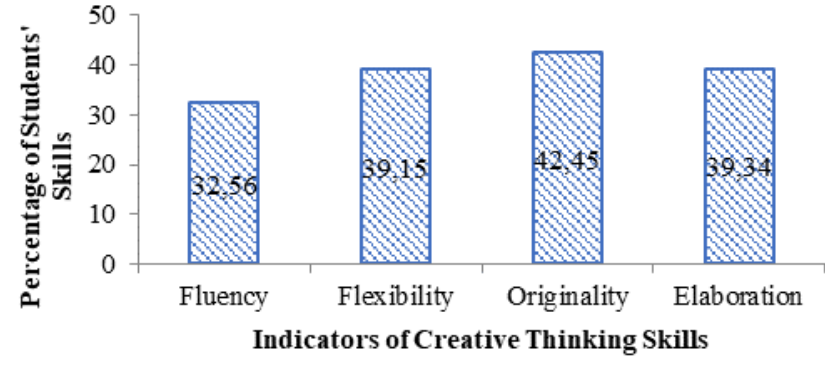

Fig. 2. The results of creative thinking skill.

Based on Figure 2, the results of students' creative thinking skills on all indicators are classified as almost the same. The highest value is the indicator of originality, which is 42.45 , and the lowest value is the indicator of fluency, which is 32.56 . Each category of the value of creative thinking skills is in Table 4.

TABLE IV.

CREATIVE SKILl VALUe CATEGoRY

\begin{tabular}{|l|l|l|}
\hline $\begin{array}{c}\text { Creative Thinking } \\
\text { Indicators }\end{array}$ & \multicolumn{1}{|c|}{ Value (\%) } & \multicolumn{1}{c|}{ Category } \\
\hline Fluency & 32,56 & Less Creative \\
\hline Flexibility & 39,15 & Less Creative \\
\hline Originality & 42,45 & Quite Creative \\
\hline Elaboration & 39,34 & Less Creative \\
\hline Average & 38,32 & Less Creative \\
\hline
\end{tabular}

The indicators of fluency, flexibility, and elaboration show the value of creative thinking skill in the category of "less creative," and the indicator of originality has a value of creative thinking skill in the category of "quite creative." The highest indicator is in the indicator of originality at $42.45 \%$. It illustrates that students can answer questions with ideas or answers using their language and way. The indicator of originality is from the answers of students who provide answers to questions in their language.

On the indicator of originality, the teacher asked students to provide examples of efforts to prevent environmental pollution, such as in the news snippets given in the questions. Students answered quite well by using their language and did not follow the preventive measures contained in the news snippets presented in the questions. The following is from interviews with students regarding the answers given to the questions with the indicator of originality.

Q: I see your answer is not in the text given. How did you fill in question number 3 ?

A: In question number 3 , it is asked to give an example of an effort to prevent environmental pollution, I just filled it according to what I know ma'am...

Q: So, you're not plagiarizing answers from others? A: No ma'am ... purely my answer. 
The indicator of fluency gets the lowest score of $32.56 \%$ with the less creative category. It illustrates that students have a low ability to provide ideas that are relevant to problemsolving.

On the indicator of fluency, students are asked to provide the right solution for the problem of polluted beaches. The problem of polluted beaches is presented in the form of news snippets contained in the questions. Students can answer correctly, but the ideas or answers given are not relevant to the common problem-solving. The following is an excerpt from interviews with students regarding their answers on the indicator of fluency.

Q: Please, try to explain the solution you gave to solve the problem of polluted beaches!

A: In my opinion, by cleaning up the rubbish on the beach, we can work together with all the residents so that the beach is clean.

$Q$ : If it has been cleaned, what else will there be? For example, the residents have worked together to clean up the trash. Uh, there are tourists who throw their garbage carelessly. You have to clean it later.

A: Oh... yes ma'am... maybe you should put up a sign "Do not throw garbage on the beach"...

The average creative thinking skills of students is $38.32 \%$ with the "Less Creative" category. It illustrates that the creative thinking skills of students at Madrasah Tsanawiyah in Majalengka are still low.

Based on the test results, the students' critical and creative thinking skills at Madrasah Tsanawiyah in Majalengka were in the low or less category. Many factors cause students to lack critical and creative thinking skills. The following are the results of an interview with a science teacher at Madrasah Tsanawiyah in Majalengka.

\section{Q: Ma'am, based on the results of the tests of} critical and creative thinking skills that have been carried out, the critical and creative thinking skills of students at Madrasah Tsanawiyah in Majalengka are in the low category. What do you think about this?

A: I have predicted that the results will be in the low category. The ability of students in learning outcomes alone shows an average of low to moderate. Students' motivation to learn is very low due to the majority of students in families with middle to low-income economies and the lack of supervisory support from parents. In addition, online learning requires students to use devices in learning. However, not all students have devices that are capable of learning.

$Q$ : What about the learning process that you have done with students?
A: In terms of the learning process, I have tried my best to use a variety of learning innovations that can be done. But back again, not all students are able to carry out the learning process because not all students have devices and/or internet quotas to study.

Similar to the findings of critical thinking skills, students creative thinking skills at MTSN 6 Majalengka are also low. The findings prove that the value of creative thinking skills is 38.32 in the less creative category. The findings of these results are reinforced by the findings of Sugiyanto and Masykuri [49], Pratiwi [50], Madyani et al. [51], and Salsabila [52], which state that the profiles of creative thinking skills in several schools are still classified as less creative or low. Concerning the low level of creative thinking skills, students' creative thinking skills in schools must have more attention [49] because creative thinking skills are one of the 21 st-century skills that are useful as a source of encouragement, driving, and strength in development, research, and investigations to face the industrial revolution [51]. Efforts to overcome students' low creative thinking skills are by trying to improve it in various ways [50]. The examples are developing interactive e-books [52], developing worksheets that are integrated with innovative learning models [53], integrating creative and innovative learning approaches and learning models [54].

The indicator of creative thinking skills with the highest value is the indicator of originality. This indicator illustrates that students can answer questions with ideas using their language and way or not following existing ideas. Based on the results of interviews with students, the answers given come purely from their ideas, not plagiarizing answers from others or seeing answers from discourse texts on questions. Creative students can generate ideas that are different from before [55] The indicator of fluency gets the lowest score on tests of creative thinking skills. It shows that students can provide ideas or answer ideas, but these answers are not relevant to the desired problem-solving. Based on the research results of Andiyana et al. [56], the cause of the low indicator of fluency of students when answering questions is because they are not careful in reading the questions so that students provide ideas or answers that are not relevant to the common problemsolving. It is in line with the results of interviews that have been conducted with students that students provide problemsolving ideas randomly, in a hurry, and ignore how the next impact of the ideas they have given.

Many factors cause students' critical and creative thinking skills to be in a low category. Based on the results of interviews with science teachers at Madrasah Tsanawiyah in Majalengka, the factors causing students' poor critical and creative thinking skills include the ability of previous students' learning outcomes, which were on less to moderate category. The findings of Siburian et al. [57], Miharja et al. [58], and Safitri et al. [59] state that there is a correlation between student learning outcomes and critical and creative thinking skills. The higher the student's cognitive results are directly proportional to the higher the student's critical or creative thinking skills. Another 
factor that causes low critical and creative thinking skills is the lack of parental participation in supervising student learning. According to Jankowska and Karwowski [60], parents who are involved in the learning process of students and the development of their children's creative thinking will produce children with higher creative thinking skills than children without parental supervision.

The social and economic status of the family has also contributed to the low critical and creative thinking skills of students at Madrasah Tsanawiyah in Majalengka. The economic status of families in the middle to a lower category means that not all students have internet devices and/or quotas to take part in this online learning process. This difficulty factor is also stated by Rigianti [61] and Jariyah and Tyastirin [62] that the obstacles in online learning include the inequality of device ownership and internet quota. Therefore, a new approach is needed to direct learning to achieve the desired competency goals, such as challenge-based learning [63]. Learning like this can train students' thinking competencies because critical and creative thinking skills can be formed [64] through exercises. It is a task and a challenge for a teacher to innovate in generating new creative ideas to create the desired learning [65].

\section{CONCLUSION}

Based on the results of the research, the students' critical and creative thinking skills at Madrasah Tsanawiyah in Majalengka are in a low category. It is indicated by the average value of the students' critical and creative thinking skills, which is below $40 \%$. The average value of critical thinking skills is 36.67 , and the average value of creative thinking skills is $38.32 \%$. The results of this study provide an overview for teachers and researchers to design and develop learning activities that can facilitate students to practice critical and creative thinking skills so that students are accustomed to thinking critically and creatively in everyday life. So that students will be able to face challenges during the Covid-19 pandemic with critical and creative thinking.

\section{ACKNOWLEDGMENT}

The writers would like to thank the Ministry of Technology Research/National Innovation Research Agency for providing funds through the Master Thesis Research grant for the 2020 Fiscal Year.

\section{REFERENCES}

[1] M.A. Shereen, S. Khan, A. Kazmi, N. Bashir and R. Siddique. COVID19 infection: Origin, transmission, and characteristics of human coronaviruses. Journal of Advanced Research, vol. 24, pp. 91-98, 2020.

[2] A.S. Abdulamir and R.R. Hafidh. The Possible Immunological Pathways for the Variable Immunopathogenesis of COVID--19 Infections among Healthy Adults, Elderly and Children. Electronic Journal of General Medicine, vol. 17, no. 4, 2020
[3] M. Aljofan and A. Gaipov, Chloroquine and COVID-19: A Light at the End of the Tunnel, or is it Another Train?. Electronic Journal of General Medicine, 17(4), 2020

[4] A. Naciri, M.A. Baba, A. Achbani, And A. Kharbach, Mobile learning in Higher education: Unavoidable alternative during COVID 19. Aquademia, 4(1), 2020.

[5] E.J. Sintema, Effect of COVID-19 on the performance of grade 12 students: Implications for STEM education. Eurasia Journal of Mathematics, Science and Technology Education, 16(7), em1851, 2020.

[6] M. Usak, A.R. Masalimova, E.I. Cherdymova and A.R. Shaidullina New playmaker in science education: COVID-19. Journal of Baltic Science Education, 19(2), 180-185, 2020.

[7] E.J. Sintema, E-Learning and Smart Revision Portal for Zambian primary and secondary school learners: A digitalized virtual classroom in the COVID-19 era and beyond. Aquademia, 4(2), ep20017, 2020.

[8] M.B. Cahapay, Rethinking Education in the New Normal Post-COVID19 Era: A Curriculum Studies Perspective. Aquademia, 4(2), ep20018, 2020

[9] C.M. Toquero, Challenges and opportunities for higher education amid the COVID-19 pandemic: The Philippine context. Pedagogical Research, 5(4), 2020.

[10] R.R. Aliyyah, R. Rachmadtullah, A.Samsudin, E. Syaodih, M. Nurtanto, and A.R.S. Tambunan,The Perceptions of Primary School Teachers of Online Learning during the COVID-19 Pandemic Period: A Case Study in Indonesia. Journal of Ethnic and Cultural Studies, 7(2), 90-109, 2020.

[11] E.M. Mulenga and J.M. Marbán, Is COVID-19 the Gateway for Digital Learning in Mathematics Education?. Contemporary Educational Technology, 12(2), ep269, 2020.

[12] I. Aripin, M.K. Sugandi, I.H. Mu'minah and A. Mulyani, Pelatihan Pembelajaran Biologi Abad 21. Bernas: Jurnal Pengabdian Kepada Masyarakat, 1(3), 150-158, 2020.

[13] I. Setyorini, Pandemi COVID-19 dan Online Learning: Apakah Berpengaruh Terhadap Proses Pembelajaran Pada Kurikulum 13?. Journal of Industrial Engineering \& Management Research, 1(1), 95-102, 2020

[14] H.I. Oktaviani, T.I. Slamet, P. Setyosari, S. Ulfa, M.U. Nofaizzi, W.P. Putra and R.D.D Kass. The Most Important Soft Skill for Students 21 st Century Learning: Contribution Technology-Enhanced in Classroom. In 2019 5th International Conference on Education and Technology (ICET) (pp. 39-42), 2019.

[15] J.A. Rios, G. Ling, R. Pugh, D. Becker,and A. Bacall. Identifying critical 21st-century skills for workplace success: a content analysis of job advertisements. Educational Researcher, 49(2), 80-89, 2020.

[16] A. Chalkiadaki. A systematic literature review of 21 st century skills and competencies in primary education. International Journal of Instruction, 11(3), 1-16, 2018

[17] E. Van Laar, A.J. van Deursen, J.A. van Dijk, and J. de Haan. 21stcentury digital skills instrument aimed at working professionals: Conceptual development and empirical validation. Telematics and Informatics, 35(8), 2184-2200, 2018

[18] L.T. Hilt, H. Riese and G.E. Søreide. Narrow identity resources for future students: The $21 \mathrm{st}$ century skills movement encounters the Norwegian education policy context. Journal of Curriculum Studies, 51(3), 384-402, 2019.

[19] L. Donovan, T.D. Green, and C. Mason. Examining the 21st century classroom: Developing an innovation configuration map. Journal of Educational Computing Research, 50(2), 161-178, 2014.

[20] M.P.K. Uminingtyas, S. Sukarmin and R. Suryana,. The Profile of 21st Century Learning: Enhancing critical thinking and problem solving skills at Senior High School. In 3rd Asian Education Symposium (AES 2018). Atlantis Press, 2019.

[21] S. Erduran, Science Education in the Era of a Pandemic: How Can History, Philosophy and Sociology of Science Contribute to Education for Understanding and Solving the Covid-19 Crisis?. Science \& Education 29:233-235, 2020. 
[22] P. Cankurtaran and M.B. Beverland. Using design thinking to respond to crises: B2B lessons from the 2020 COVID-19 pandemic. Industrial Marketing Management, 88, 255-260, 2020.

[23] T.D.C. Nakano and S.M. Wechsler. Creativity and innovation: Skills for the 21st Century. Estudos de Psicologia (Campinas), 35(3), 237-246, 2018 .

[24] A. Khalili. Creativity and innovation through LMX and personal initiative, Journal of Organizational Change Management, Vol. 31 No. 2, pp. 323-333, 2018.

[25] A. Rahardjanto. Hybrid-PjBL: Learning Outcomes, Creative Thinking Skills, and Learning Motivation of Preservice Teacher. International Journal of Instruction, 12(2), 179-192, 2019.

[26] J. Siburian, A.D. Corebima, and M. Saptasari. The correlation between critical and creative thinking skills on cognitive learning results. Eurasian Journal of Educational Research, 19(81), 99-114, 2019.

[27] A.J. Khoiriyah and H. Husamah. Problem-based learning: Creative thinking skills, problem-solving skills, and learning outcome of seventh grade students. JPBI (Jurnal Pendidikan Biologi Indonesia), 4(2), 151$160,2018$.

[28] E. Care, H. Kim, A. Vista and K. Anderson. Education System Alignment for 21st Century Skills: Focus on Assessment. Center for Universal Education at The Brookings Institution, 2018.

[29] S.Y. Ariadhy, S. Nurohman, D. Arkum, W. Handini, and F. Ferdiana Pelatihan Pembelajaran Jarak Jauh Di Era Pandemi Covid-19. Jurnal Anoa, 1(3), 220-226, 2018.

[30] N. Eryadini, D. Nafisah and A. Sidi. Psikologi Belajar Dalam Penerapan Distance Learning. Jurnal Pendidikan dan Pengabdian Masyarakat, 3(3), 2020.

[31] S. Suciati. Improvement Of Teacher Creativities And Initiatives Through Online Learning Models In The Covid-19 Pandemic Period. Ideguru: Jurnal Karya Ilmiah Guru, 5(1), 79, 2020.

[32] H. Ardiansyah. Pengaruh Metode Pembelajaran Brainstroming terhadap Kemampuan Berpikir Kritis berdasarkan Kemampuan Awa siswa. Indonesian Journal of Economic Education (IJEE), 1(1), 2018.

[33] W. Widayati, S. Suyono,and W. Rahayu. Pengaruh Model Pembelajaran Berbasis Penemuan Terhadap Kemampuan Berpikir Kritis Matematis Dan Self Concept Dengan Mengontrol Kemampuan Awal siswa Kelas VII SMP. JPPM (Jurnal Penelitian dan Pembelajaran Matematika), 11(1), 2018.

[34] H. Sulistyaningrum, A. Winata, and S. Cacik. Analisis Kemampuan Awal 21st Century Skills Mahasiswa Calon Guru SD. Jurnal Pendidikan Dasar Nusantara, 5(1), 142-158, 2019.

[35] P.L. Barreiro and J.P. Albandoz. Population and sample. Sampling techniques. Management mathematics for European schools, 1(1), 1-18, 2001.

[36] S.M. Wechsler, C. Saiz, S.F. Rivas, C.M.M. Vendramini, L.S. Almeida M.C. Mundim, and A. Franco. Creative and critical thinking: Independent or overlapping components? Thinking Skills and Creativity, $27,114-122,2018$.

[37] S. Arikunto. Prosedur Penelitian: Suatu Pendekatan Praktik. Edisi Revisi VI, Jakarta: PT Rineka Cipta, 2017.

[38] E.C. Rahayu. The critical thinking ability profile of grade X SMA N 2 Kudus. In Journal of Physics: Conference Series (Vol. 1567, No. 3, p. 032086), 2020.

[39] R.K. Dewi, S. Wardani and N. Wijayati. Profile of students critical thinking skills on redox concept in SMA Negeri 8 Semarang. In Journal of Physics: Conference Series. Vol. 1321, No. 2, p. 022048, 2019.

[40] N.N. Alifia and D.R.S Saputro. Mathematical critical thinking skills profile of high school students in solving linear program word problems. In Journal of Physics: Conference Series (Vol. 1211, No. 1, p. 012101), 2019.

[41] A.S. Widodo and W. Sunarmo. Early profile analysis of student's critical thinking in material system circulation in XI MIA class of high school in Surakarta. In IOP Conference Series: Earth and Environmental Science (Vol. 243, No. 1, p. 012125), 2019.
[42] E.C. Rahayu. The critical thinking ability profile of grade X SMA N 2 Kudus. In Journal of Physics: Conference Series (Vol. 1567, No. 3, p. 032086), 2020.

[43] C. Rivers and I. Kinchin. Dynamic Learning: Designing a Hidden Pedagogy to Enhance Critical Thinking Skills Development. Management Teaching Review, 4(2), 148-156, 2019.

[44] I. Nurhikmayati and M.G. Jatisunda. Scientific Learning to Improve Critical Thinking Ability. Eduma: Mathematics Education Learning and Teaching, 7(2), 1-10, 2018.

[45] S. Anggraini, W. Setyaningrum and H. Retnawati. How to improve critical thinking skills and spatial reasoning with augmented reality in mathematics learning?. In Journal of Physics: Conference Series (Vol. 1581, No. 1, p. 012066), 2020.

[46] P. Nunthaitaweekul, S. Chaijaroen and R. Gamlunglert. The Framework for Development of Constructivist Web-Based Learning Environmen Model to Enhance Critical Thinking for Primary Students. In International Conference on Innovative Technologies and Learning (pp. 644-652), 2019.

[47] S.W. Chew, I.H. Lin and N.S. Chen. Using Socratic Questioning Strategy to Enhance Critical Thinking Skill of Elementary Schoo Students. In 2019 IEEE 19th International Conference on Advanced Learning Technologies (ICALT) (Vol. 2161, pp. 290-294), 2019.

[48] I. Nurhikmayati and M.G. Jatisunda. Scientific Learning to Improve Critical Thinking Ability. Eduma: Mathematics Education Learning and Teaching, 7(2), 1-10, 2018.

[49] I.S.K. Ulfa, D. Trapsilasiwi, And E. Yudianto, E. Profil Berpikir Kritis Siswa dalam Menyelesaikan Soal Fungsi Komposisi melalui Model Pembelajaran Kolaboratif. Jurnal Didaktik Matematika, 5(1), 40-53, 2018.

[50] N. Rahimah, Profil Berpikir Kritis Siswa Dalam Memecahkan Masalah Matematika Berdasarkan Kemampuan Matematika. Lentera: Jurnal Pendidikan, 14(1), 2019.

[51] L. Yuliati, R. Fauziah and A. Hidayat. Student's critical thinking skills in authentic problem based learning. In Journal of Physics: Conference Series (Vol. 1013, No. 1, pp. 0-6), 2018

[52] F.N. Sugiyanto and M. Masykuri. Analysis of senior high schoo students' creative thinking skills profile in klaten regency. JPhCS, 1006(1), 012038, 2018.

[53] R.D. Pratiwi. Profile of Students' Creative Thinking Skills using Openended Multiple Choice Test in Science Learning. In Journal of Physics Conference Series (Vol. 1397, No. 1, p. 012020), 2019.

[54] I. Madyani, S. Yamtinah, S.B. Utomo, S. Saputro, and L. Mahardiani. Profile of Students' Creative Thinking Skills in Science Learning. In 3rd International Conference on Learning Innovation and Quality Education (ICLIQE 2019) (pp. 957-964), 2020.

[55] H. Salsabila. Profile of Creative Thinking Skills Students in One of Public Junior High School in Surakarta. BIOSFER: Jurnal Biologi dan Pendidikan Biologi, 3(1), 13-19, 2018

[56] F.N. Sugiyanto and M. Masykuri. Analysis of senior high school students' creative thinking skills profile in klaten regency. JPhCS, 1006(1), 012038, 2018.

[57] I. Madyani, S. Yamtinah, S.B. Utomo, S. Saputro and L. Mahardiani. Profile of Students' Creative Thinking Skills in Science Learning. In 3rd International Conference on Learning Innovation and Quality Education (ICLIQE 2019) (pp. 957-964), 2020.

[58] H. Salsabila. Profile of Creative Thinking Skills Students in One of Public Junior High School in Surakarta. BIOSFER: Jurnal Biologi dan Pendidikan Biologi, 3(1), 13-19, 2018.

[59] N.B. Mutia and Z.K. Prasetyo. The Effectiveness of Students' Worksheet Based on Multiple Representations to Increase Creative Thinking Skills. Journal of Education and Learning (EduLearn), 12(4), 631-637, 2018.

[60] I. Krisdiana, T. Masfingatin, W. Murtafiah, and S.A. Widodo Worksheet-Based Learning Research to Improve Creative Thinking 
Skills. In Journal of Physics: Conference Series, vol. 1254, no. 1, p. 012054, 2019

[61] M. Tohir, Z. Abidin, D. Dafik, and H. Hobri. Students creative thinking skills in solving two dimensional arithmetic series through researchbased learning. IOP Conf. Series: Journal of Physics: Conf. Series 1008, 012072, 2018

[62] P. Yaniawati, R. Kariadinata, N. Sari, E. Pramiarsih, and M. Mariani. Integration of e-Learning for Mathematics on Resource-Based Learning: Increasing Mathematical Creative Thinking and SelfConfidence. International Journal of Emerging Technologies in Learning (iJET), 15(6), 60-78, 2020.
[63] R. Ramadhani, F. Farid, F. Lestari, and A. Machmud. Improvement of Creative Thinking Ability through Problem-Based Learning with Local Culture Based on Students' Gender and Prior Mathematics Ability. AlJabar: Jurnal Pendidikan Matematika, 11(1), 61-72, 2020.

[64] M. Wojciehowski and J. Ernst. Creative by Nature: Investigating the Impact of Nature Preschools on Young Children's Creative Thinking. International Journal of Early Childhood Environmental Education, 6(1), 3-20, 2018.

[65] S. Suratno, N. Komaria, Y. Yushardi, Dafik, and I. Wicaksono. The Effect of Using Synectics Model on Creative Thinking and Metacognition Skills of Junior High School Students. International Journal of Instruction, 12(3), 2019. 